\title{
MENINGKATKAN PERAN INKUBATOR BISNIS SEBAGAI KATALIS PENCIPTAAN WIRAUSAHA DI ASIA PASIFIK: TINJAUAN EKONOMI MAKRO
}

\begin{abstract}
Arif Darmawan
Universitas Lampung; arif.darmawan@feb.unila.ac.id

Abstrak

Inkubator bisnis telah terbukti secara efektif dalam menciptakan lapangan kerja dan mempercepat pertumbuhan bisnis baru. Tujuan dari makalah ini adalah untuk menyelidiki dan mengidentifikasi situasi dan faktor-faktor inkubator bisnis sebagai katalis untuk memfasilitasi keberhasilan implementasi seperti, 1) pengusaha muda, 2) penciptaan lapangan kerja, dan 3) pemberdayaan usaha kecil dan menengah (UKM). Sifat penelitian ini terutama adalah pendekatan metode campuran seperti studi kasus dan kualitatif (tinjauan literatur) dan kemudian, melakukan pemeriksaan dengan studi kasus Asia Pasifik. Beberapa data diambil melalui referensi dari jurnal, artikel, dan laporan inkubator bisnis. Ekspansi yang cepat dari inkubator bisnis di Asia, terutama Asia Pasifikadalah salah satu fenomena paling penting yang mempengaruhi pertumbuhan ekonomi. Studi ini menemukan bahwa pengalaman dan karakteristik industri inkubasi di Asia menunjukkan bahwa, banyak perhatian dan dukungan besar dari pemerintah pusat dan / atau lokal, memberikan dorongan kuat untuk industri inkubasi. Di sisilain, kemitraan dan berbagi di antara para inkubasi adalah komponen penting untuk membuat inkubator lebih sukses. Temuan penelitian ini dapat membantu pemerintah dan pembuat kebijakan agar implementasi berhasil. Juga, tambahkan dan perluas pengetahuan baru untuk literatur akademik tentang inkubator, wirausah, dan pengembangan ekonomi.
\end{abstract}

Kata Kunci: Inkubator Bisnis, Katalis Penciptaan, Ekonomi Makro

\section{PENDAHULUAN}

Ekonomi global telah memburuk lebih lanjut dan proyeksi pertumbuhan telah ditandai. Masalah utama adalah apakah ekonomi global hanya memukul yang lain tentang turbulensi dalam apa yang selalu diharapkan menjadi pemulihan yang lambat dan bergelombang atau apakah perlambatan saat ini memiliki komponen yang lebih tahan lama. Indikator aktivitas dan pengangguran menunjukkan peningkatan dan kelesuan ekonomi berbasis luas dari tahun ke tahun.

Orang-orang muda yang menganggur di seluruh dunia mungkin tidak segera melihat situasi mereka membaik. Ketika krisis kawasan euro berlanjut di tahun kedua, dampaknya menyebar lebih lanjut, memperlambat ekonomi dari Asia Timur ke Amerika Latin. Di negara maju, tingkat pengangguran kaum muda diperkirakan akan turun di tahun-tahun mendatang, setelah mengalami peningkatan terbesar di antara semua wilayah pada awal krisis, tetapi terutama karena orang-orang muda yang putus asa menarik diri dari pasar tenaga kerja dan bukan karena kekuatan yang lebih besar: mempekerjakan aktivitas di kalangan anak muda. Terlepas dari penurunan ini dan meskipun para penganggur muda di negara maju mewakili 13 persen dari total populasi pekerja di dunia, tingkat pengangguran kaum muda global diperkirakan akan terus meningkat lebih tinggi dari tahun depan (GEO, 2012). 


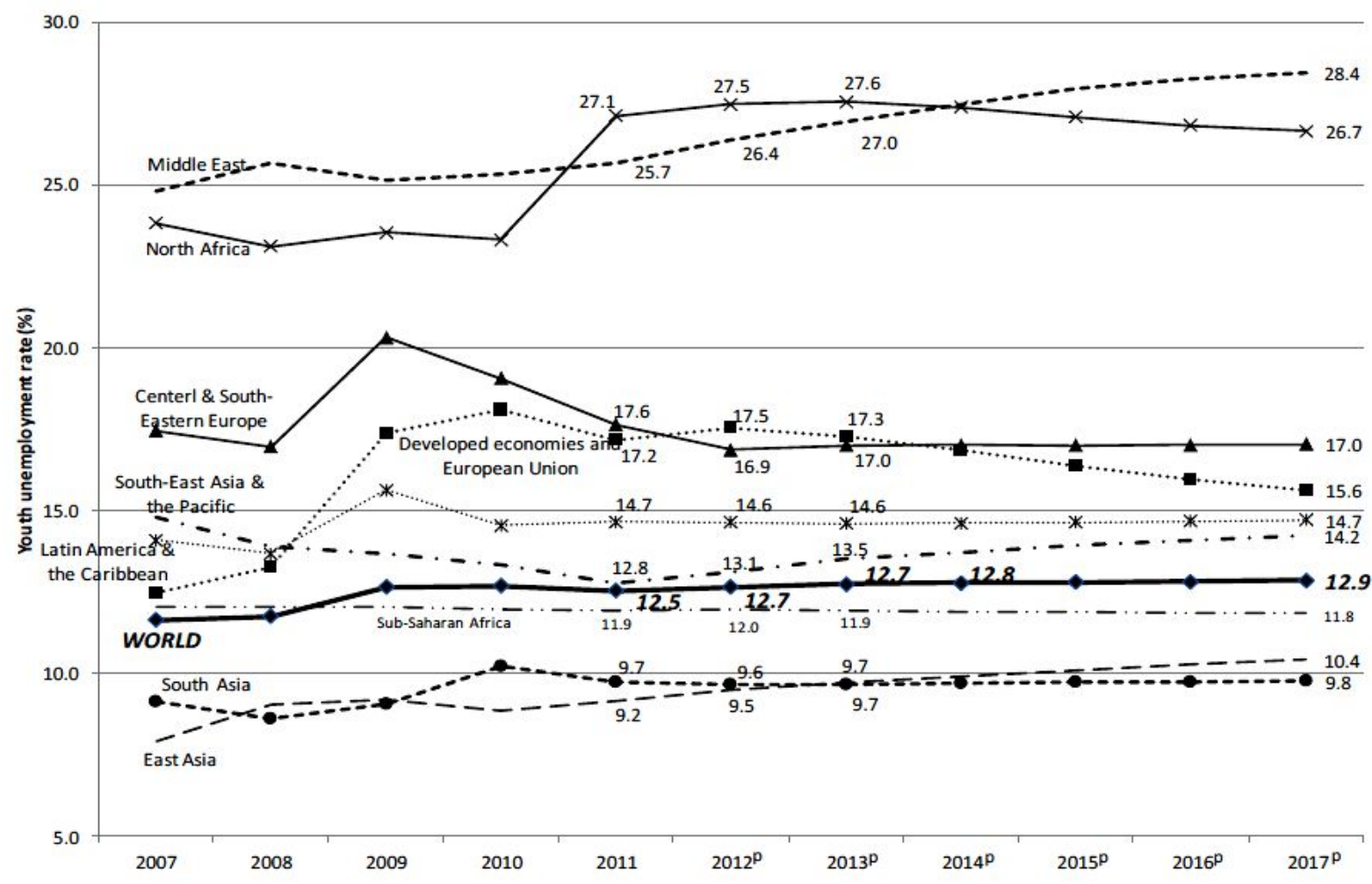

Gambar 1. Tingkat Pekerjaan Pemuda Skala Global dan Regional (15 - 24 tahun)

(Sumber: ILO, Tren Econometrics Model, Juli 2012; IMF World Economic Outlook, 2012)

Pengangguran terbuka adalah masalah yang harus dihadapi di negara berkembang dan maju.Mengingat tidak tersedianya sistem jaminan sosial yang komprehensif dan andal, secara teoritis ada insentif yang sangat tinggi untuk tetap bekerja, terutama di kalangan masyarakat miskin. Sementara itu, orang miskin yang tidak bekerja, dan sampai batas tertentu orang tidak miskin yang berpendidikan rendah dan menganggur, cenderung menjadi pekerja yang kecil hati. Mereka adalah orang-orang yang kehilangan pekerjaan tetapi tidak mencari pekerjaan karena mereka percaya bahwa mereka tidak dapat menemukannya akibat skill yang tidak mumpuni (Kingdon dan Knight, 2006; Suryadarma, Suryahadi, dan Sumarto, 2005).

Dalam upaya mengurangi pengangguran, penting untuk memastikan bahwa jenis pekerjaan yang diciptakan dalam suatu ekonomi cocok dengan keterampilan dan harapan para penganggur. Sebagai contoh, inkubator bisnis, yang membantu bisnis baru memulai, semua sumber daya yang diperlukan atau dukungan yang dibutuhkan perusahaan baru untuk berkembang dan tumbuh sebagai bisnis yang matang. Inkubator bisnis adalah istilah umum yang merujuk pada organisasi atau pengusaha muda mana pun yang menyediakan ruang kerja fisik, bantuan manajemen, akses ke pembiayaan dan layanan pendukung teknis dan lainnya kepada perusahaan-perusahaan muda dan membantu mereka bertahan dan tumbuh selama tahap awal (Yong Suk dan Mooweon, 2006).

Konsep inkubasi bisnis, yang muncul selama tahun 1970-an di AS dan Eropa meledak dalam popularitas di seluruh dunia sebagai model bisnis modern. Menurut perkiraan National Business Incubation Association (NBIA), ada sekitar 15 inkubator di Amerika Utara pada 1980, tetapi saat ini 600 inkubator berlokasi di Amerika Utara saja. Inkubator bisnis membantu wirausahawan menerjemahkan ide-ide mereka menjadi bisnis yang bisa diterapkan dan berkelanjutan dengan memandu mereka dari awal hingga mampu mencapai bisnis yang tumbuh dan berkembang. Inkubasi bisnis memberi para pengusaha keahlian, jaringan, dan alat yang mereka butuhkan untuk membuat 
bisnis mereka sukses. Sejalan dengan maraknya pendirian inkubator bisnis,

Saat ini, kita dapat dengan mudah menemukan konsep dan aktivitas inkubator bisnis ini di negara berkembang dan negara-negara non-barat. Dalam kasus Indonesia sebagai negara yang mengembangkan inkubator bisnis sejak 1992, konsep dasar inkubator adalah lembaga yang menyediakan 7S; 1.Ruangmengacu pada ruang kantor, 2. Fasilitas kantor bersama yang merupakan penyediaan fasilitas kantor yang dapat digunakan bersama, seperti faks, telepon, fotokopi, ruang rapat, komputer, dan sekretariat. 3. Layanan mengacu pada bimbingan dan konsultasi manajemen, pemasaran, keuangan, produksi, dan teknologi. 4. Dukungan yang berarti membantu untuk mendukung dan mengakses penggunaan teknologi, 5. Pengembangan Keterampilan terkait dengan pelatihan, persiapan rencana bisnis, pelatihan manajemen, dan sebagainya. 6.Modal Benih adalah dana awal serta upaya untuk mendapatkan akses modal ke lembaga keuangan. 7.Sinergi mengacu pada penciptaan jaringan bisnis di antara bisnis secara lokal dan internasional.

Terlepas dari meningkatnya jumlah inkubator bisnis, banyak masalah dalam operasi dan organisasi inkubator tersebut muncul karena kurangnya pelatihan manajer dan staf inkubasi yang cakap, post-manajemen dan jejaring inkubator yang kurang terstruktur, dan kegagalan untuk beradaptasi dengan bisnis lokal lingkungan. Makalah ini menyajikan kondisi inkubator secara global, mengusulkan faktor, dan menemukan situasi yang membuat inkubator bisnis dapat menjadi katalisator untuk menciptakan dan mempromosikan wirausaha.

\section{TINJAUAN PUSTAKA}

\subsection{Inkubator Bisnis}

Menurut definisi, inkubator bisnis dapat dianggap sebagai strategi pengembangan usaha yang bertujuan untuk membantu dan mempercepat prosespembentukan, pengembangan, dan kemampuan bertahan hidup dari perusahaan baru dan yang sudah ada di masyarakat. Ini dilakukan dengan mengumpulkan sumber daya potensial termasuk bisnis potensial (klien) dari masyarakat dalam fasilitas inkubator bisnis dan kemudian menyediakan klien dengan berbagai layanan bantuan bisnis (Abduhet al, 2007; Rice dan Mathews, 1995).

Inkubator bisnis adalah organisasi yang mendukung proses kewirausahaan, membantu meningkatkan tingkat kelangsungan hidup bagi wirausahawan yang inovatif. Pengusaha dengan proyek layak dipilih dan dimasukkan ke dalam inkubator, di mana mereka ditawarkan menu khusus sumber daya dukungan dan layanan. Sumber daya dan layanan yang terbuka untuk wirausahawan dapat mencakup beragam elemen seperti:

- pembinaan manajemen

- membantu dalam menyiapkan rencana bisnis yang efektif

- layanan administratif

- dukungan teknis

- jaringan bisnis

- membantu dalam menemukan sumber daya keuangan

Konsep inkubator bisnis dapat dijelaskan pada Gambar 2 di bawah ini. Dapat dilihat dari gambar bahwa tujuan dari inkubator bisnis adalah untuk membawa orang-orang dengan ide dan mengirim mereka keluar dengan usaha yang sukses. Dalam prosesnya, inkubator bisnis mengakses pengetahuan, keahlian, teknologi, jaringan, dana, dan pasar. 


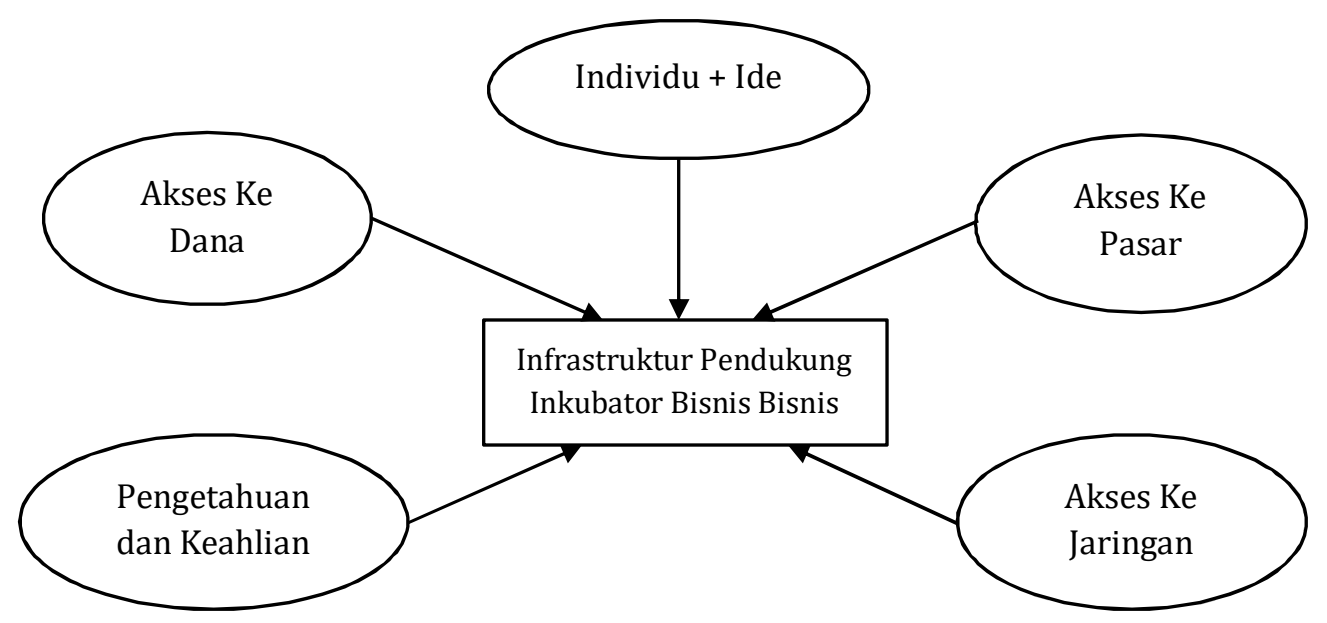

Gambar 2. Konsep Inkubator Bisnis (Sumber: Sahay, 2005)

Hannon (2003) menganggap bahwa proses inkubasi bisnis mendukung identifikasi dan eksploitasi peluang sukses untuk penciptaan usaha bisnis baru. Menurut Hannon (2003), proses inkubasi bisnis harus dihadapi, pertama, sebagai lingkungan di mana ide dan usaha bisnis baru dapat dikembangkan sesuai dengan serangkaian sumber daya pendukung bisnis. Peran yang dilakukan oleh inkubator bisnis, dengan menopang generasi perusahaan kompetitif baru, atau dengan melatih wirausahawan masa depan, adalah sangat penting.

Ada tiga tahap inkubasi (lihat Gambar 3):

1. Ciptaan awal (Pra-inkubasi) berhubungan dengan keseluruhan kegiatan yang diperlukan untuk mendukung wirausahawan potensial dalam mengembangkan ide bisnis, model bisnis, dan rencana bisnis, dan untuk meningkatkan peluang untuk sampai pada kreasi awal yang efektif.

2. Tahap awal (inkubasi) berkaitan dengan dukungan yang diberikan kepada wirausahawan dari awal hingga fase ekspansi. Biasanya ini adalah proses jangka menengah, biasanya berlangsung selama tiga tahun pertama aktivitas perusahaan yang baru didirikan, yaitu tahuntahun di mana aman untuk mengatakan apakah usaha baru ini berhasil dan memiliki peluang yang baik untuk berkembang menjadi perusahaan yang sepenuhnya matang. Tindakan yang diaktifkan umumnya adalah akses ke keuangan, layanan bimbingan dan pendampingan langsung, serta layanan hosting dan pelatihan khusus. Oleh karena itu, inkubasi fisik, meskipun layanan yang sangat penting, adalah bagian dari keseluruhan proses inkubasi.

3. Ekspansi (Pasca inkubasi) berkaitan dengan kegiatan yang akan dilakukan ketika perusahaan telah mencapai fase jatuh tempo, dan karenanya siap untuk berjalan dengan kakinya sendiri. Perusahaan akan meninggalkan inkubator, jika telah diinkubasi secara fisik. Inkubator berbasis inovasi bekerja di persimpangan antara serangkaian inovasi dan wirausaha pendukung wirausaha untuk mendapatkan keuntungan dari nilai tambah ide-ide inovatif.

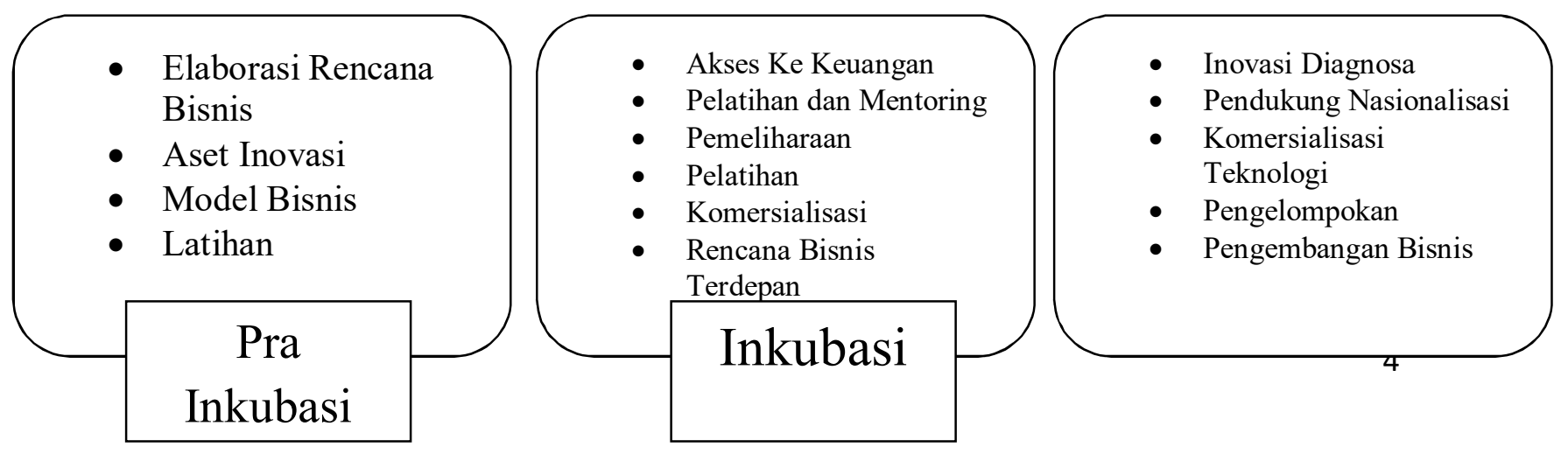


Gambar 3. Tahapan Proses Inkubasi (Sumber: Al-Mubaraki dan Busler, 2008)

Hackett dan Dilts (2004a) mendefinisikan inkubator adalah konsep yang kuat karena inkubator adalah alat untuk mengumpulkan dan mengatur kekuatan yang ada untuk memfasilitasi penciptaan perusahaan. Inkubator bisnis juga menambah nilai bagi perusahaan dan wirausahawan yang melakukan tinjauan komprehensif dan terperinci tentang program inkubasi di mana mereka tertarik.

\section{METODE}

Metodologi penelitian yang telah digunakan dalam penelitian ini dikompromikan dengan desk-research dan tinjauan literatur. Makalah ini adalah produk studi yang dilakukan pada literatur tentang pengembangan inkubator bisnis dari materi yang diterbitkan, buku teks, presentasi konferensi, artikel, dan jurnal.Penelitian desk ekstensif dilakukan untuk meninjau dan menilai studi yang ada yang relevan dengan inkubator bisnis dan fenomena tentang masalah tersebut.

Saat mencari materi yang dipublikasikan tentang inkubator bisnis, artikel dipilih menggunakan istilah pencarian berikut: dampak inkubator; penilaian inkubator; efektivitas inkubator; efisiensi inkubator, dan model. Untuk menghindari membandingkan hasil penelitian yang ditujukan untuk fenomena yang berbeda, Bergek dan Norman (2008) tinjauan layanan inkubator diadopsi untuk pemilihan kertas dalam kasus metode tinjauan literatur. Artikel selanjutnya diidentifikasi berdasarkan daftar literatur.

\section{HASIL DAN PEMBAHASAN}

\section{1) Konsep dan Peran Inkubator Bisnis Saat ini}

Inkubator adalah jaringan pendukung bisnis yang umum dikaitkan dan program inovasi teknologi. Para ahli konsep telah sepakat bahwa inkubasi bisnis kecil adalah proses yang dinamis di mana perusahaan-perusahaan muda dibina untuk membantu mereka bertahan hidup dan tumbuh selama periode ketidakpastian, terutama selama fase permulaan. Inkubator dirancang untuk mengatasi kegagalan pasar yang melekat seperti akses yang tidak adil ke informasi dan modal serta kurangnya fokus saran bisnis untuk bisnis kecil baru (Campbell, 1989). Inkubator bisnis biasanya digambarkan sebagai fasilitas yang menyediakan kondisi terkendali yang menguntungkan untuk membantu pertumbuhan usaha baru (Petreeet al., 1997). Mereka juga disebut sebagai pusat inovasi, pusat perusahaan, dan pusat perusahaan bisnis atau pusat teknologi (Petree et al., 1997).

Sebagai pengantar, inkubator pertama, pusat laba swasta, didirikan pada tahun 1959 di Batavia, New York (Brown). et al., 2000). Konsep inkubator menyebar secara internasional sesudahnya. Salah satu inkubator pertama di Eropa didirikan di Cambridge Science Park dan Sophia Antipolis di Prancis pada akhir 1960-an (Storey dan Tether, 1998). Konsensus yang dicapai oleh peneliti adalah bahwa kontribusi utama inkubator adalah kemampuan mereka untuk meningkatkan tingkat kelangsungan hidup bisnis baru. Artinya, penulis studi ini menyarankan bahwa inkubasi bisnis (dan) adalah alat pengembangan bisnis yang efektif.

Kerangka kerja yang disebutkan di bawah ini (Gambar 4) merangkum bahwa elemen-elemen kunci dalam keberhasilan seorang wirausahawan baru yang terletak di sebuah inkubator tampaknya adalah lembaga sponsor, layanan inkubator, dan pengusaha. 


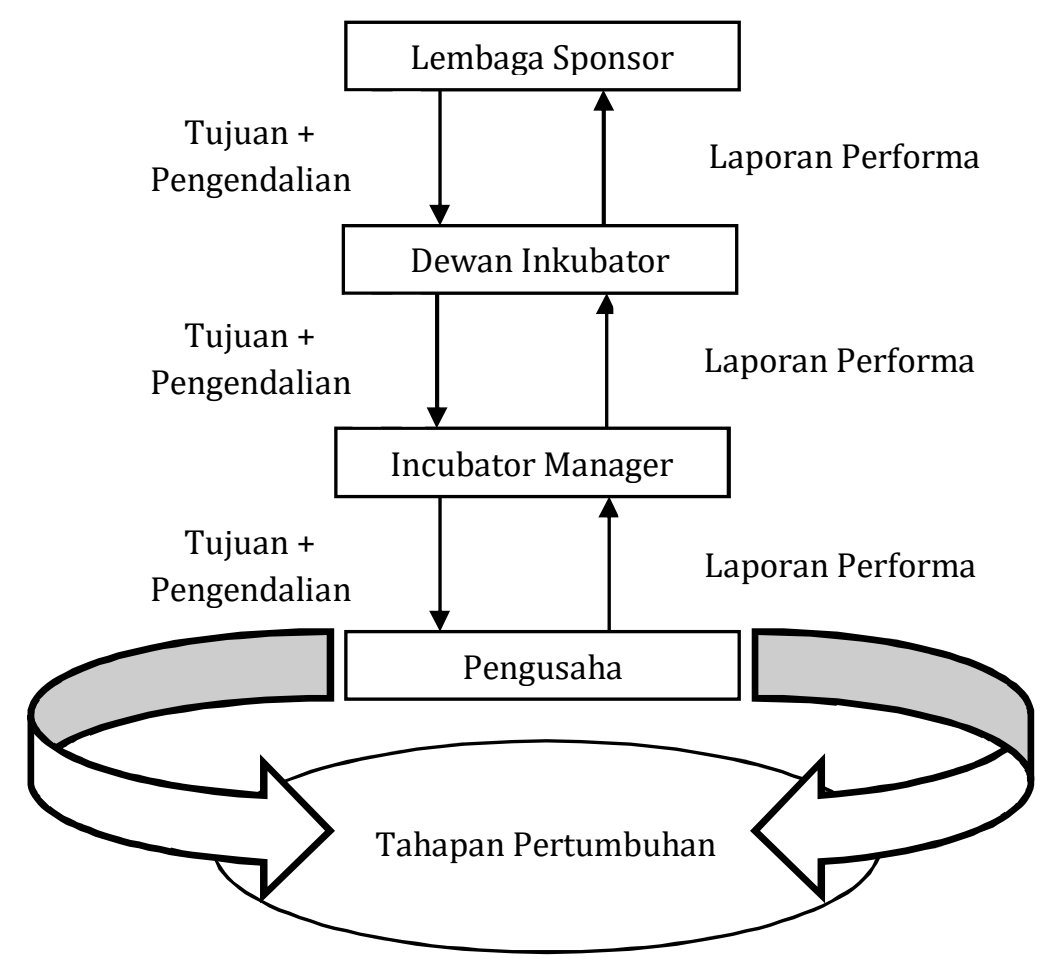

Gambar 4. Kerangka Pertumbuhan dalam Inkubator Bisnis (Sumber: Remedios dan Cornelius, 2003)

Inkubator bisnis mempercepat keberhasilan pengembangan perusahaan wirausaha melalui serangkaian sumber daya dan layanan pendukung bisnis, yang dikembangkan atau diatur oleh manajemen inkubator, dan ditawarkan baik di inkubator maupun melalui jaringan kontaknya. Di antara generasi pertama dari inkubator, mayoritas berfokus pada bisnis teknologi yang relatif rendah, biasanya di sektor jasa dan manufaktur. Secara bertahap, industri inkubasi berkembang dalam ukuran dan kecanggihan bisnis yang diwakili di antara perusahaan klien.

Aktivitas wirausaha tidak sama di semua negara, wilayah, dan kota. Kewirausahaan dikondisikan oleh berbagai faktor yang menetap dalam perilaku, motivasi, dan pengetahuan individu. Namun, itu tergantung pada peluang dan sumber daya yang tersedia dan pada kondisi lingkungan sekitarnya (Stathopoulous, Psaltopoulus, Skuras, 2004). Seperti yang terlihat di atas, banyak model inkubasi bisnis yang dikembangkan dan digunakan secara luas di pusat-pusat inkubasi bisnis, inkubator bisnis universitas, inkubator swasta independen, inkubator pribadi perusahaan, inkubator bisnis teknologi tinggi, dan taman teknologi. Jelas, lingkungan ideal untuk kewirausahaan adalah di mana perusahaan dapat mengambil keuntungan dari aglomerasi dan kedekatan sumber-sumber informasi, tenaga kerja yang berkualitas, teknologi, dan modal. Model inkubasi klasik berkembang pesat di lingkungan tersebut. Menurut Moreira dan Marta (2009), jenis inkubator ide bisnis ini sangat inovatif karena memberikan pendekatan langsung untuk melatih calon wirausahawan. Metodologi berorientasi aksi ini mendukung calon wirausahawan sebelum penciptaan bisnis baru yang sebenarnya.

2) Faktor dan Performa Inkubator Bisnis: Contoh Asia Pasifik 
Pada bagian berikut, tujuan utama dari sistem inkubasi di Asia adalah untuk mempromosikan industri regional dan nasional yang berkelanjutan, pertumbuhan ekonomi melalui peningkatan lapangan kerja, pengembangan bisnis umum, dan untuk merangsang tujuan ekonomi tertentu seperti restrukturisasi industri serta pembangkitan kekayaan dan pemanfaatan sumber daya nasional. China, Jepang, India, Korea, Indonesia, Malaysia, dan anggota lain dari kawasan Asia dan Pasifik menganut inkubasi bisnis. Asia memimpin dalam pendirianinkubator bisnis. Sebagian besar, status inkubator yang mengelola beragam, termasuk universitas atau lembaga akademik, pemerintah, organisasi nonpemerintah, dan sektor swasta.

Ada lebih dari 1.500 inkubator yang beroperasi di Asia Tengagra saja. China sendiri memiliki lebih dari 600 inkubator dibandingkan dengan lebih dari 50 inkubator di India (16 di antaranya adalah inkubator bisnis teknologi) dan 100 inkubator dalam tahap perencanaan oleh pemerintah India. Jepang, Taiwan, Korea Selatan, dan Indonesia juga mengikuti sebagai negara yang memiliki banyak inkubator (Cho dan Eunsuk, 2009). Inkubator telah menjadi pembawa penting untuk membangun negara yang berorientasi inovasi dan tempat lahir untuk menumbuhkan perusahaan teknologi dan pengusaha. Tren di Asia adalah semakin banyak perusahaan yang diinkubasi karena semakin banyak inkubator didirikan dan jumlah karyawan meningkat.

Tabel 1. menunjukkan analisis studi kasus termasuk nama negara dengan tujuan utama program inkubator dengan layanan yang disediakan oleh inkubator dan jumlah inkubator di setiap negara.

Tabel 1.Analisis Inkubator Bisnis di Negara-negara Asia Pasifik

\begin{tabular}{|c|c|c|c|c|}
\hline No & Negara & $\begin{array}{c}\text { Jumlah Inkubator } \\
\text { Bisnis di Setiap } \\
\text { Negara }\end{array}$ & Tujuan & Jasa yang Ditawarkan \\
\hline 1 & Australia & 23 & \multirow{13}{*}{$\begin{array}{ll}\text { 1. } & \text { Penciptaan } \\
\text { Pekerjaan } \\
\text { 2. }\end{array}$} & \multirow{13}{*}{$\begin{array}{l}\text { 1. Manajemen yang mengembangkan } \\
\text { dan mengatur sumber daya bisnis, } \\
\text { pemasaran, dan manajemen serta } \\
\text { hubungan yang disesuaikan } \\
\text { dengan kebutuhan klien bisnis. } \\
\text { 2. Layanan kantor bersama, } \\
\text { pelatihan, teknologi, dukungan, } \\
\text { dan peralatan. } \\
\text { 3. Pemilihan klien dan proses } \\
\text { akselerasi. } \\
\text { 4. Bantuan dalam memperoleh } \\
\text { pembiayaan yang diperlukan } \\
\text { untuk pertumbuhan bisnis. }\end{array}$} \\
\hline 2 & Bangladesh & 15 & & \\
\hline 3 & Cina & 600 & & \\
\hline 4 & India & 57 & & \\
\hline 5 & Indonesia & 84 & & \\
\hline 6 & Jepang & 136 & & \\
\hline 7 & Malaysia & 40 & & \\
\hline 8 & Mongolia & 9 & & \\
\hline 9 & Pakistan & 22 & & \\
\hline 10 & Singapura & 61 & & \\
\hline 11 & Taiwan & 18 & & \\
\hline 12 & Thailand & 29 & & \\
\hline 13 & Vietnam & 17 & & \\
\hline
\end{tabular}

Sumber: Al-Mubaraki dan Busler, 2011.

Pengalaman dan karakteristik industri inkubasi di Asia menunjukkan bahwa; banyak perhatian dan dukungan besar dari pemerintah pusat, tuangkan dorongan kuat untuk industri inkubasi. Kebijakan yang baik tentang usaha kecil dan menengah oleh pemerintah dapat memberikan dampak yang signifikan untuk mengembangkan sistem inovasi nasional. Kebijakan pemerintah dan kerja sama masing-masing negara di Asia untuk mendukung pembentukan dan pengembangan inkubator bisnis adalah langkah penting untuk mewujudkan inkubator bisnis sebagai katalis untuk menciptakan wirausaha muda. Sebagai contoh di Korea, 95\% inkubator berlokasi di universitas atau pusat penelitian dan sebagian besar bisnis pemula. $71.1 \%$ terutama di bidang teknik atau sains 


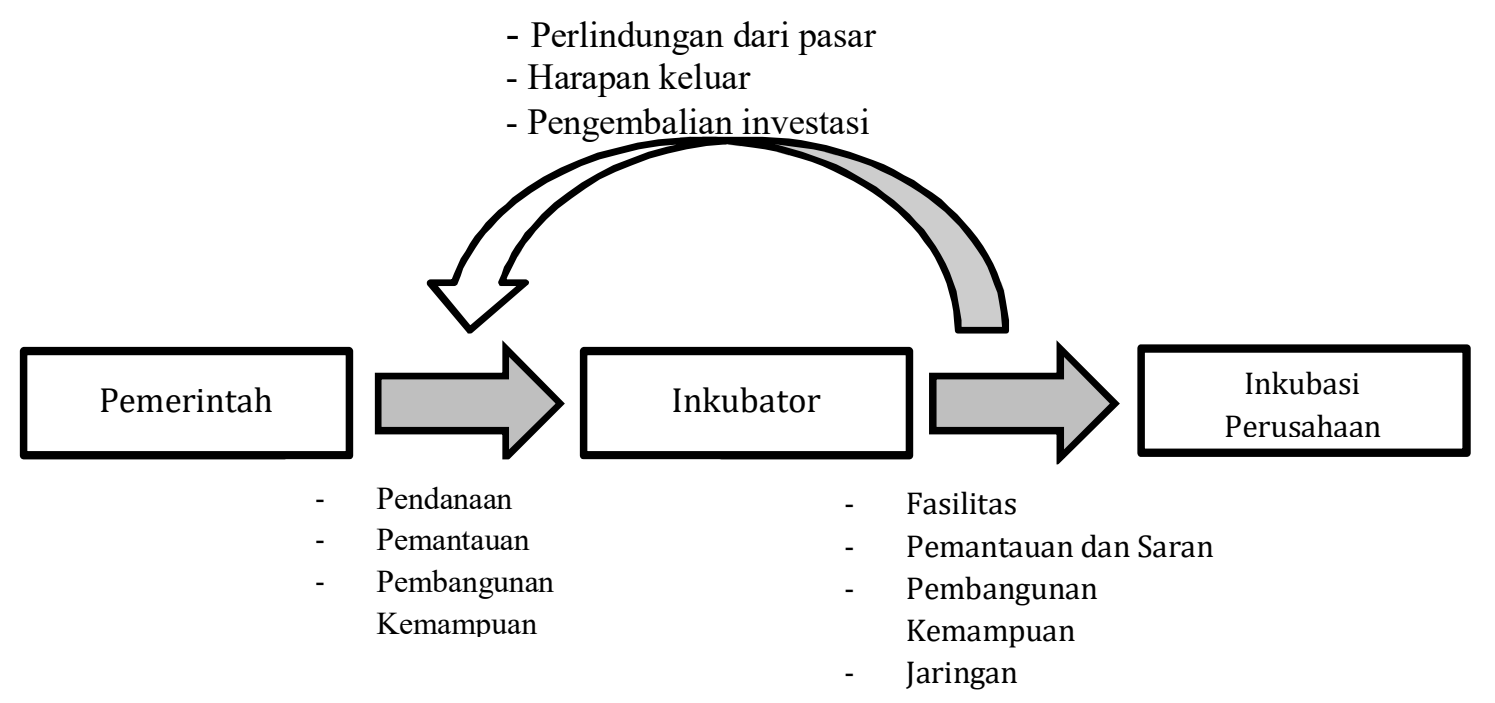

Gambar 6. Model Kebijakan - Inkubator Inkubator (Sumber: Lane, 2009)

Inkubator bisnis, saat ini, menjadi lebih dan lebih populer di kalangan pengusaha dan berbagai manfaat dan layanan yang ditawarkan oleh manajer inkubator untuk perusahaan baru di seluruh dunia terutama di Asia. Selain itu, inkubator bisnis menawarkan berbagai potensi manfaat pengembangan ekonomi. Dampak aktualnya terhadap perkembangan ekonomi umumnya diukur dalam hal jumlah pekerjaan yang diciptakan, tingkat kelulusan perusahaan, dan penerimaan pajak (Lourenco, 2004). Membangun inkubator di wilayah ini terus berinovasi dengan tantangan dengan menginternasionalkan perusahaan domestik mereka yang sukses, mengatasi kesenjangan keuangan tahap awal, meningkatkan Diasporas, dan mengembangkan perusahaan teknologi yang menguntungkan. Inkubator di Asia, sebagian besar,

Melihat peran inkubator dalam proses kewirausahaan, Wiggins dan Gibson (2003) berpendapat bahwa inkubator harus melakukan lima hal dengan baik untuk berhasil:

1. Menetapkan metrik yang jelas untuk sukses;

2. Memberikan kepemimpinan kewirausahaan;

3. Mengembangkan dan memberikan layanan bernilai tambah kepada perusahaan anggota;

4. Mengembangkan proses seleksi perusahaan baru yang rasional;

5. Pastikan perusahaan anggota mendapatkan akses ke sumber daya manusia dan keuangan yang diperlukan.

Dengan membangun inkubator bisnis dan menghubungkannya dengan inisiatif klaster, ini akan merangsang jejaring antar perusahaan, terutama dengan perusahaan yang lokasinya berdekatan satu sama lain. Ini juga akan meningkatkan inkubator bisnis dan afiliasi (perusahaan) untuk melakukan kolaborasi bersama melalui pengetahuan dan teknologi. Oleh karena itu, promosi inkubasi sebagai alat penting dalam pengembangan cluster masuk akal, karena strategi pengembangan cluster dapat mempertimbangkan kecukupan fasilitas yang 
tersedia untuk pengembangan cluster yang diidentifikasi. Ketersediaan tempat kerja dan layanan dukungan bisnis bagi calon wirausahawan dan perluasan bisnis yang ada adalah komponen penting untuk mempertahankan keberhasilan jangka panjang sebuah cluster.

Dalam penelitian lain, kemampuan untuk memfasilitasi jaringan muncul sebagai faktor pembeda utama (Hansen, Chesbrough, Nohria dan Sull, 2000; Hanses, Nohria dan Berger, 2000). Hansen dan rekannya berpendapat bahwa satu jenis inkubator, yang disebut inkubator jaringan, mewakili model organisasi baru yang berhasil cocok untuk menumbuhkan bisnis teknologi tinggi. Ini berbagi fitur umum dengan inkubator lain dalam arti bahwa ia memberikan inkubasi dengan fisik, ruang kerja, peralatan, dan dukungan administrasi dan manajerial. Namun, fitur utamanya yang dapat dibedakan adalah kemampuannya untuk mendorong jejaring di antara para inkubasi dan membantu para pemula untuk bertemu dengan sekutu bisnis potensial. Jejaring di antara para pemula termasuk berbagai kegiatan dari interaksi informal seperti melakukan percakapan santai sehari-hari dan berbagi ide hingga kegiatan yang lebih formal seperti membentuk kemitraan teknologi dan berbagi direktori yang saling terkait. Hansenet al., tekankan bahwa kemitraan dan berbagi di antara para inkubasi adalah komponen penting untuk membuat inkubator lebih sukses. Penulis setuju bahwa mendorong jejaring di antara para inkubasi adalah faktor keberhasilan yang penting bagi para inkubator. Oleh karena itu, inkubator bisnis dapat berkontribusi untuk merangsang lebih banyak pengusaha untuk mengejar impian mereka untuk menciptakan perusahaan mereka sendiri.

\section{KESIMPULAN}

Ada banyak faktor yang berkontribusi terhadap inkubator bisnis. Untuk mengembangkan kinerja komprehensif inkubator bisnis sebagai katalis, kinerja inkubator atau perusahaan baru yang masuk dan lulus dari inkubator harus dilacak. Secara khusus, kami menemukan bahwa inkubator menjadi lebih produktif ketika mereka memberikan inkubasi dengan berbagai macam dukungan teknis, manajerial, dan administrasi untuk kualitas yang lebih baik. Selain itu, saya percaya bahwa inkubator jaringan yang lebih baik berperforma lebih baik. Menurut penelitian dan literatur sebelumnya, jaringan internal dan eksternal yang aktif adalah salah satu sumber utama program inkubasi yang sukses. Inkubator yang berhasil harus dapat mempromosikan jejaring internal di antara inkubat dan mengembangkan jejaring eksternal dengan berbagai pelaku seperti lulusan, modal ventura, pemerintah daerah,

Di sisi lain, pengalaman dan karakteristik industri inkubasi di Asia Pasifik menunjukkan bahwa; banyak perhatian dan dukungan besar dari pemerintah pusat memberi dorongan kuat untuk industri inkubasi. Kebijakan yang baik tentang usaha kecil dan menengah oleh pemerintah dapat memberikan dampak yang signifikan untuk mengembangkan sistem inovasi nasional. Kebijakan pemerintah dan kerja sama masing-masing negara di Asia Pasifik untuk mendukung pembentukan dan pengembangan inkubator bisnis adalah langkah penting untuk mewujudkan inkubator bisnis sebagai katalis untuk menciptakan wirausaha muda.

\section{REFERENSI}




\section{Buku}

Abduh, M., C. D’Souza, A. Quazi, and H.T. Burley. (2007). Building Futures or Stealing Secrets?: Entrepreneurial Cooperation and Conflict within Business Incubators. Managing Service Quality, 17 (1), pp. $74-91$.

Akcomak, S. (2009). Incubators as Tools for Entrepreneurship Promotion in Developing Countries. November 2009. Research Paper No. 2009/52 in UNU-WIDER.

Allen, D. N. (1985). Business Incubators: Assessing Their Role in Enterprise Development. Economic Development Commentary, Vol. 9, No. 4, pp. 3 - 7.

Allen, D. N. and Bazan, E. (1990). Value Added Contributions of Pennsylvania's Business Incubators to Client Firms and Local Economies. Report Prepared for the U.S. Department of Commerce, Economic Development Administration, Washington, DC.

Al-Mubaraki, Hanadi Mubarak and Busler, Michael. (2011). Entrepreneurship Spirit of Asia Business Incubator.

Al-Mubaraki, Hanadi Mubarak and Busler, Michael. (2008). The Incubators Economic Indicators: Mixed Approaches. Journal of Case Research in Business and Economics, pp. 1 - 12.

Bergek, A., and C. Norrman. (2008). Incubator Best Practice: a Framework. Technovation, 28, pp. 20 -28 .

Brown, M, Harrell, MP, Regner W. (2000). Internet Incubators: How to Invest in the New Economy without Becoming as Investment Company. Business Lawyer, 56(1): pp. $273-284$.

Bruton, G. D. (1998). Incubators as a Small Business Support in Russia: Contrast of UniversityRelated U.S. Incubators with the Zelenograd Scientific and Technology Park. Journal of Small Business Management, Vo. 36, No. 1, pp. $91-94$.

Campbell, C. (1987). Changes Agents in the New Economy: Business Incubators and Economic Development. Minneapolis, MN: University of Minnesota Press.

Campbell, C. (1989). Change Agents in the New Economy: Business Incubators and Economic Development. Economic Development Review, 7(2), pp. 56 - 59.

Cho, B. J. and Eunsuk, S. (2009). The Role of Dynamics of the IKED, Government Agencies Supporting Institutes, and Incubation Centers in Korea. APKIE Volume 3, No. 2, 2009, pp 57 - 75.

Colombo, M. G. and Delmastro, M. (2002). How Effective are Technology Incubators?: Evidence from Italy. Research Policy, 31 (7), pp. $1103-1122$.

Dowling, P. (1997). Business Incubation in Australia: Best Practice Standards and an Industry Profile. ANZABI.

Hansen, M.T., Chesbrough H. W., Nohria, N., and Sull, D. N. (2000). Networked Incubators: Hothouses of the New Economy. Harvard Business Review, September/October.

Harwit, E. (2002). High Technology Incubators: Fuel for China, New Entrepreneurship? The China 
Business Review, Vol. 29, No. 4, pp. 26 -29.

ILO. (2012). Global Employment Outlook: Break Labour Market Prospect for Youth.

IMF. (2012). World Economic Outlook, October 2012: Coping with High Debt and Sluggish Growth. International Monetary Fund, Publication Services, Washington, DC, USA.

Kingdon, Geeta. and John Knight. (2006). The Measurement of Unemployment When Unemployment is High. Labour Economics, 13 (3), pp. $291-315$.

Lalkaka, R. (2003). Business Incubators in Developing Countries: Characteristics and Performance. International Journal and Innovation Management, Vol. 3 No. 1/2, pp/ 31 - 55.

Lane, Christoper. (2009). Incubating Incubators: The New Zealand Policy of Cutting the Cord. Asia Pacific Journal of Innovation and Entrepreneurship, Volume 3 No. 2, August 2009, pp. 33.

Lee, D. H. (1997). Korea's System and Policy towards Technology Incubators in OECD. Technology Incubators: Nurturing Small Business, pp. 98 - 105.

Lichtenstein, G. A. (1993). The Significance of Relationships in Entrepreneurship: a Case Study of the Ecology of Enterprise in Two Business Incubators. Unpublished Ph.D. Dissertation University of Pennsylvania, US.

Lourenco, M. S. (2004). Understanding Communications Network Development and Business Incubation: an Analysis of Three Incubators in Louisville, Kentucky. A dissertation submitted to the Faculty of the Graduate School of the University of Louisville in partial fulfillment of the Ph.D.

Mian, S. A. (1996). Assessing Value-Added Contribution of University Technology Business Incubators (UTBIs) to Client Firms. Research Policy, Vol. 25, No. 3, pp. 325 - 335.

Moreira, A. C., and Martins, S. L. (2009). CRER: An Integrated Methodology for the Incubation of Business Ideas in Portugal. Journal of Enterprising Communities: People and Places in the Global Economy, Vol. 3, No. 2, pp. $177-192$.

Nolan, A. (2003). Public Policy on Business Incubators: an OECD Perspective. International Journal of Entrepreneurship and Innovation Management, Vol. 3, No 1/2, pp. 22 - 30.

Remedios, R.K. Bhabra and Cornelius, B. (2003). Cracks in the Egg: Improving Performance Measures in Business Incubator Research. Small Enterprise Association of Australia and New Zealand, $16^{\text {th }}$ Annual Conference, Ballarat, 28 Sept - 1 Oct, 2003.

Rice, M., and Matthews, J. 1995. Growing New Ventures, Creating New Jobs - Principles and Practices of Successful Business Incubation. Centre of Entrepreneurial Leadership Inc. Quorum Books.

Sahay, A. (2005). The Role of Technology Business Incubator, Angel Investor, and Venture Capital Fund in Industrial Development.

Smilor, R. W. (1987). Managing the Incubator System: Critical Success Factors to Accelerate New Company Development. IEEE Transactions on Engineering Management, Vol. 34, No. 4, pp 146 - 
156.

Stathopoulou, S., Psaltopoulos, D., and Skuras, D. (2004). Rural Entrepreneurship in Europe, a Research Framework and Agenda. International Journal of Entrepreneurial Behavior and Research, Vol. 10, No. 6, pp. $404-425$.

Storey, D.J., Tether, B.S. (1998). Public Policy Measures to Support New Technology Based Firms in the European Union Research Policy.

Suryadarma, Daniel, Suryahadi, Asep, and Sumarto, Sudarno. (2005). The Measurements and Trends of Unemployment in Indonesia: The Issue of Discouraged Workers. SMERU Working Paper. SMERU Research Institute, Jakarta.

$\mathrm{Xu}$, L. (2010). Business Incubation in China: Effectiveness and Perceived Contributions to Tenant Enterprises. Management Research Review, Vol. 33, No. 1, pp. 90 - 99.

Yong Suk, Jang and Mooewon, Rhee. (2006). Resource Mobilization and Business Incubation: The Case of Korean Incubators. Development and Society, Volume 35 Number 1, June 2006, pp. 29 - 46.

Yunos, M. G. M. (2002). Building an Innovation-based Economy: The Malaysian Technology Business Incubator Experience. Journal of Change Management, Vol. 3, No. 2, pp. 177 - 188.

\section{Buku Elektronik}

Hackett, S.M., and Dilts, D.M. (2004). A Real Options-Driven Theory of Business Incubation. Journal of Technology Transfer, Volume 29, No. 1, January 2004, pp. 41 - 54, available at: SRRN: http://ssrn.com.

Petree R., Petkov R., and Spiro, E. (1997). Technology Parks-Concept and Organization. Summary Report prepared for Center for Economic Development, Sofia, at http://ced.bg/

Wiggins, J. and Gibson, D. V. (2003). Overview of US Incubators and the Case the Austin Technology Incubator. International Journal Entrepreneurship and Innovation Management, Vol. 3. Nos. V, pp 56 - 66. Available at: http://bth.se/eng/library.

\section{For an organizational or government report or document with no author(s):}

NBIA. (2010). Business Incubation FAQ. http://nbia.org. 